\title{
Erratum to: Measurement and estimation of plastic greenhouse reference evapotranspiration in a Mediterranean climate
}

\author{
M. D. Fernández $\cdot$ S. Bonachela $\cdot$ F. Orgaz $\cdot$ \\ R. B. Thompson · J. C. López • M. R. Granados • \\ M. Gallardo $\cdot$ E. Fereres
}

Published online: 28 September 2010

(C) Springer-Verlag 2010

\section{Erratum to: Irrig Sci (2010) 28:497-509 \\ DOI 10.1007/s00271-010-0210-z}

Following publication of the paper, the authors have detected a calculation error in the calibration of the FAO56 Penman-Monteith method used for estimating greenhouse reference evapotranspiration $\left(\mathrm{ET}_{\mathrm{o}}\right)$. There is an error in the value of aerodynamic resistance $\left(r_{\mathrm{a}}\right)$ presented in the paper.

While a standard value of $150 \mathrm{~s} \mathrm{~m}^{-1}$ was reported for the aerodynamic resistance $\left(r_{\mathrm{a}}\right)$ in the paper, we found subsequently that the correct value of $r_{\mathrm{a}}$, that provides the best agreement between estimated and measured daily greenhouse $\mathrm{ET}_{\mathrm{o}}$ values, as determined by minimizing the root mean square error (RMSE) with the SOLVER procedure (Microsoft ${ }^{\circledR}$ Excel 2002), is $295 \mathrm{~s} \mathrm{~m}^{-1}$. Measured $\mathrm{ET}_{\mathrm{o}}$ data from 1993 and 1994 (without whitening), and from 2000 and 2001 (with whitening) were used for model calibration. With a fixed $r_{\mathrm{a}}$ value of $295 \mathrm{~s} \mathrm{~m}^{-1}$, the FAO56 Penman-Monteith method was validated using measured $\mathrm{ET}_{\mathrm{o}}$ values from 1995 , 1997 and 1999 (without whitening), and from 2002, 2003 and 2004 (with whitening). The FAO56 Penman-Monteith with a fixed $r_{\mathrm{a}}$ of $295 \mathrm{~s} \mathrm{~m}^{-1}$ correctly predicted measured values; it presented a slight underestimation of $6 \%$ without whitening $\left(\mathrm{RMSE}=0.37 \mathrm{~mm} \mathrm{day}^{-1}, \mathrm{MBE}=-0.078 \mathrm{~mm}\right.$ $\mathrm{day}^{-1}$ and $\mathrm{RE}=-3.3 \%$ ) and of $2 \%$ with whitening $\left(\mathrm{RMSE}=0.38 \mathrm{~mm} \mathrm{day}^{-1}, \mathrm{MBE}=-0.047 \mathrm{~mm} \mathrm{day}^{-1}\right.$ and $\mathrm{RE}=-2.3 \%$ ).

Figure $6 \mathrm{c}$ and $\mathrm{d}$, and Table 2 of the paper are presented here again since the values showed were affected by the change in the $r_{\mathrm{a}}$ value.

After making the above corrections, no further changes were required in the "Results", "Discussion" and "Conclusions" sections of the paper.

The online version of the original article can be found under doi:10.1007/s00271-010-0210-z.

M. D. Fernández $(\varangle)$ · J. C. López

Estación Experimental de la Fundación Cajamar, 04710 El Ejido, Almería, Spain

e-mail: mdoloresfernandez@fundacioncajamar.com

S. Bonachela · R. B. Thompson · M. R. Granados · M. Gallardo

Departamento de Producción Vegetal,

Universidad de Almería, 04120 Almería, Spain

F. Orgaz

Instituto de Agricultura Sostenible (IAS),

CSIC, Apartado 4084, 14080 Córdoba, Spain

E. Fereres

IAS-CSIC and Departamento de Agronomía,

Universidad de Córdoba, Apartado 3048,

14080 Córdoba, Spain 


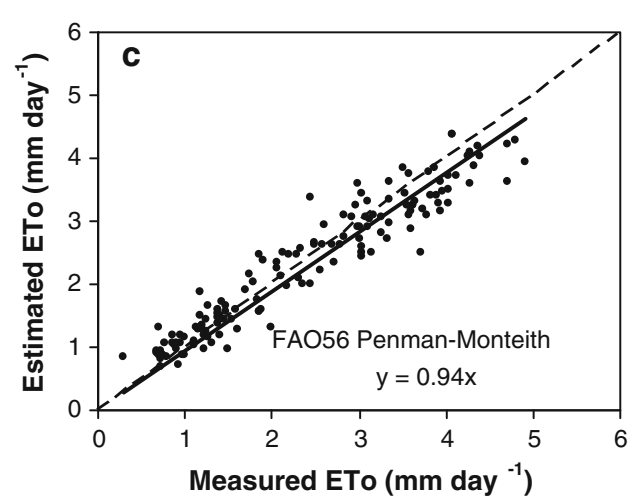

Fig. 6 Comparison between mean daily values of estimated and measured $\mathrm{ET}_{\mathrm{o}}$ values in a plastic greenhouse with (from 2002 to 2004) and without whitening (from 1995 to 1999). $\mathrm{ET}_{\mathrm{o}}$ values were estimated by FAO24 Pan method using a constant $\mathrm{Kp}$ value of 0.79

Table 2 Summary of statistics from the comparison between estimated $\left(\mathrm{E}, \mathrm{mm}\right.$ day $\left.^{-1}\right)$ and measured $\left(\mathrm{O}, \mathrm{mm} \mathrm{day}^{-1}\right)$ data of mean daily greenhouse $\mathrm{ET}_{\mathrm{o}}$ with (2002-2004) and without whitewash

\begin{tabular}{|c|c|c|c|c|c|c|c|c|c|}
\hline $\mathrm{ET}_{\mathrm{o}}$ method & $N$ & $O$ & $E$ & $E / O$ & Slope & $r^{2}$ & RMSE & MBE & $\mathrm{RE}$ \\
\hline & \multicolumn{9}{|c|}{ Greenhouse without whitening } \\
\hline \multirow[t]{2}{*}{ FAO56 Penman-Monteith $\left(r_{\mathrm{a}}=295 \mathrm{~s} \mathrm{~m}^{-1}\right)$} & 144 & 2.41 & 2.33 & 0.97 & 0.94 & 0.98 & 0.37 & -0.08 & -3.3 \\
\hline & \multicolumn{9}{|c|}{ Greenhouse with whitening } \\
\hline FAO56 Penman-Monteith $\left(r_{\mathrm{a}}=295 \mathrm{~s} \mathrm{~m}^{-1}\right)$ & 30 & 2.06 & 2.10 & 1.02 & 0.98 & 0.97 & 0.38 & -0.05 & -2.3 \\
\hline
\end{tabular}

$N$ total number of observations; slope of the regression equation, $r^{2}$ coefficient of determination, $R M S E$ root mean square error (mm day ${ }^{-1}$ ), $M B E$ mean bias error $\left(\mathrm{mm} \mathrm{day}^{-1}\right), R E$ relative error $(\%)$

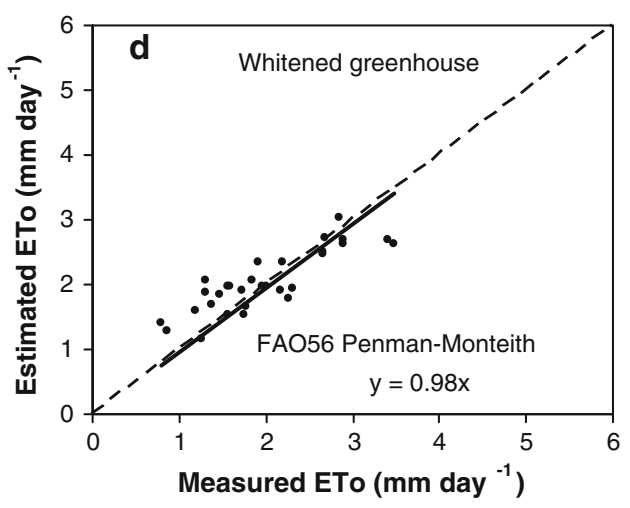

(a, b), FAO56 Penman-Monteith using a fixed aerodynamic resistance value of $295 \mathrm{~s} \mathrm{~m}^{-1}$ (c, d). Each point corresponds with a daily $\mathrm{ET}_{\mathrm{o}}$ value, averaged over a week, throughout a particular year

(1995-1999) for FAO56 Penman-Monteith method using a fixed aerodynamic resistance value of $295 \mathrm{~s} \mathrm{~m}^{-1}$ 